\title{
A scientific defence of religion and the religious accommodation of science? Contextual challenges and paradoxes
}

\begin{abstract}
Author:
Cornel W. du Toit ${ }^{1}$

Affiliation:

${ }^{1}$ Research Institute for

Theology and Religion,

University of South Africa,

South Africa

Note:

This article was initially delivered as a paper at a plenary session of the Joint Conference of Theological Societies in Southern Africa, University of KwaZulu-Natal, Pietermaritzburg, 18-22 June 2012
\end{abstract}

Correspondence to: Cornel du Toit

Email:

dtoitcw@unisa.ac.za

Postal address:

PO Box 780, Groenkloof

0027, South Africa

\section{Dates:}

Received: 02 July 2012

Accepted: 01 Feb. 2013

Published: 08 May 2013

How to cite this article: Du Toit, C.W., 2013, 'A scientific defence of religion and the religious accommodation of science? Contextual challenges and paradoxes', HTS Teologiese Studies/Theological Studies 69(1), Art. \#1293, 9 pages. http://dx.doi.org/10.4102/ hts.v69i1.1293

\section{Copyright:}

(C) 2013. The Authors. Licensee: AOSIS OpenJournals. This work is licensed under the Creative Commons Attribution License.

Read online:
Few human phenomena in our time are as controversial or confusing as religion. People seem to live in two worlds: a mythical and a scientific one. They talk about either of these worlds in isolation but cannot reconcile the underlying presuppositions. Believers are less naïve than the 'new atheists' suppose, and atheists do not come without their quota of superstition and belief. Midway between the two opposites is a burgeoning, secular new spirituality that has assumed many forms in recent years. The groups are often marked by some form of naturalism, which try to accommodate science. The premise in this article is that religion, being a product of normal evolutionary processes, is 'natural'. This implies that cultural evolution is ongoing and supports the thesis that religion (in this case Western Christianity) is making a major transition. As for science, I briefly outline the role of metaphysics. That is because science often has to invoke metaphysical constructs to make sense of the bigger picture. Following Aristotle, the metaphysical dimension of science is a blank page which every era fills with its own interpretation. In that sense, it is 'more than' just empiricism, verifiability, and it is accompanied by some metaphysical baggage. At this metaphysical level, the traditional dominance of causality makes way for emergence.

\section{Introduction}

Religion features prominently in the public arena, albeit in controversial mode. This is evident in a constant stream of anti-religious - more especially anti-Christian - publications. There are many reasons: the conflict potential of religion, highlighted by the $9 / 11$ catastrophe; the rise of Muslim fundamentalism; the aggressiveness of so-called new atheism; the exodus of members from mainline churches; the proliferation of spiritual groups and movements; the progressive annexation of traditionally religious areas by the state (human rights, ethics) and by science (cosmology, health). Pascal Boyer (2010:10) questions the existence of religion, rendering absurd the idea of a science-religion debate. In his view, the traditional religions are confined to people's immediate, personal situation and are not about academic issues. From his anthropological angle, he writes that:

most religious thought is not about the creation of the world, ... is rarely about God, ... is very seldom about the salvation of the soul ... People use their religious concepts to account for their uncle's death or their child's illness or their neighbour's good fortune, not to explain the persistence of evil or the existence of the universe. (Boyer 2010:13)

Hence he shoots down theology: '[M]ost human societies throughout history have managed to have religion without theology' (Boyer 2010:14). To some extent, one has to concede his point at a global level. Theology is largely confined to the Christian West, and even there, it is changing. Nonetheless one can hardly overestimate the influence of Christian theology, despite all the metaphysical overtones it once had and still displays.

Boyer (2010) does not regard church dogma or religion's metaphysical heritage as a normal part of human religious experience:

In places where a doctrine is available, indeed where people are taught that doctrine, and themselves believe they hold beliefs typical of the doctrine, there is a large and converging evidence that their actual thoughts and intuitions diverge widely from the doctrine. (p. 14)

Thus the accent is on personal circumstances and the role of religion in these.

Despite the prominence of 'new atheism', religion is by no means disappearing. ${ }^{1}$ It is, however, in a transitional stage. Berger predicts that the 21 st century may well be the most

1.Whereas Europe is becoming increasingly post-religious as far as Christianity is concerned, this religion is growing phenomenally in Latin America, Africa and Asia. However, the growth is mainly in Pentecostal and neo-Pentecostal contexts, centring on a literal reading of the Bible, miracles, charismatic gifts and healing. Grassie (2010:66) affirms this: 'In fact, the fastest-growing religions in the world today are Islam, Pentecostal Christianity, and amorphous New Age-type syntheses.' More than $16 \%$ of all Americans say that they do not participate in organised religion (Leaves 2011:6, 9, 37). The number of adherents of Islam is also growing dramatically, although Leaves (2011:10) attributes it to population growth rather than new converts. 
religious century in 500 years (Grassie 2010:54)! The critical question, of course, is whether it matters whether religion is growing at the grassroots level if the God of theology (God of modernism) is dead. If religion is still growing, it is because people are uninformed. Badiou (2006) writes:

I take the formula 'God is dead' literally. It has happened ... God is finished. And religion is finished, too ... What is ultimately important here is to figure out the subjective mechanism explaining how people can so easily believe that it is nothing of the sort and that religion prospers; or even, as it is so often said at this time, that religion returns. (p. 23)

But even if the theologians' God is dead, is he also dead at an intellectual level? ' ... [T] he death of the God of religion leaves the question of the destiny of the God of metaphysics unresolved' (Badiou 2006:26).

In this article, the metaphysical God features as the tenacious explanatory principle of the final ground of reality (or aspects of it) in theology, philosophy and science.

\section{Religion is natural}

The question of what is natural, unnatural and supernatural is extremely complex and cannot be explored here. Suffice it to say that concepts like nature and culture are temporally bound. In its universal manifestation, religion may be regarded as a natural expression of human needs - of probing for meaning and understanding. Questions about agency and origin are intrinsically human. Where do things come from, why do they happen and who or what causes them? Agency, causality and determinism remain fundamental issues in philosophy and religion and will be discussed in more detail below.

Even though human needs and the search for meaning and understanding are natural, the traditional solutions do not necessarily coincide with present-day scientific ideas. However, the mainline religions are bound by texts (revelation), so adjustments are difficult. The challenge is to harmonise religious tenets like miracles, creation stories and visions of the future with contemporary interpretations of reality. Ancient stories tied to the self-interpretation and worldview of those times can be reinterpreted metaphorically so as still to convey a meaningful message. Of course, I do not profess to speak for all believers, but there are plenty of examples of attempts of this kind.

If one accepts the aforementioned challenge, a feasible option would be to focus on a theology 'from below' - which could be described as a naturalistic exercise. It presupposes that naturalism is an open rather than a closed system, that reality encompasses transcendence and makes it possible. It is an attempt to meet the sciences on the level playing field of the physical world as we know it today. It includes the evolution of life to the supreme level of human consciousness and all it entails. I deliberately avoid taking (unprovable) faith as a point of departure since such a stance precludes interdisciplinary dialogue. If reason is suspended Kantian fashion to accommodate faith, theology has little to say to science. If faith is natural, it must be accepted as a particular outcome of the evolution of life on earth, albeit confined to its supreme manifestation in human consciousness and thought. The contents of consciousness and human thought can be criticised but not denied or eliminated. Religion must be appraised as one of the most meaningful mental phenomena that characterises many human lives.

Religion can be regarded as natural even though most religions are characterised by faith in the supernatural. Grassie (2010) maintains that religion is not necessarily supernatural ${ }^{2}$ and does not inevitably involve a relationship with the supernatural. By definition, the supernatural eliminates the possibility 'that religions may intuit and infer, discern and discover, something empirically real and ontologically profound about the universe as a whole and human life within the universe' (Grassie 2010:45). It does not deny that religion recounts 'supernatural' stories to be regarded as imaginative myths. According to Grassie (2010:45-46), however, the mythologies could afford deeper insight into the human condition and a transcendent reality that can be substantiated both empirically and philosophically. Wolpert (1993) affirms this:

Unlike science, religion is based on unquestionable certainties. It is neither easy nor natural for most people to live with uncertainty, and religion can provide a solution to many problems, particularly moral ones. Thus all religious belief can be regarded as natural. (p. 144)

Religion is natural because it is part of the evolution of humankind as an intelligent species. In that sense, superstition, fantasy and all sorts of irrationality are equally natural. ${ }^{3}$ But fantasy, superstition and irrationality are usually shrugged off or have little influence whereas, traditionally, human lives were dominated by religion. Yet humans are also capable of logical thought and modify their behaviour in light of substantiated information and facts. In view of modern scientific knowledge, has religion not become redundant? We no longer need supernatural powers to explain the cosmos and live meaningful lives. Despite all this, religion, far from disappearing, is growing and fundamentalism persists ${ }^{4}$ in the face of criticism. Various reasons are advanced for this phenomenon. Humans are not purely rational but are also affective beings that need explanatory systems and a sense of security to cope with misfortune, illness and death. Cupitt (quoted in Leaves 2011:181) observes: 'Religion is primarily not about belief, but about hope.' Religion is so interwoven with culture that it cannot conceivably be excised from architecture, art, literature and other religiously inspired cultural artefacts.

2.Leaves (2011:181) points out that many people (in Sweden and Denmark) ${ }^{\prime} \ldots$ live in accordance with a non-supernatural, non-creedal humanism that has its origins in Christianity'.

3.Even if religion in the traditional sense were to die out, it does not guarantee the end of human naivety, superstition and irrationality. These feed the gambling industry, present-day superstitions, the popularity of science fiction, unscientific health and rejuvenation practices and the like.

4.Christian theology is pre-eminently textual, because the book, canon or revelation was so focal in Christian religion from the outset. This was reinforced by the Reformation with its emphasis on texts and reached a zenith in 19th century 'higher criticism'. But growing hermeneutic and exegetical insight, structuralism, 'higher criticism'. But growing hermeneutic and exegetical insight, structuralism,
post-structuralism and, later, postmodernism failed to eradicate the prevailing fundamentalism of ecclesiastic practice. 
God's existence cannot be verified or falsified. But one can believe in him, even if faith is not proof. For committed believers, their faith in and experience of God are so powerful that they are sufficient proof of his existence. So even if God cannot be proven, one can prove that, for many people, he is the very ground of reality: He is a reality within the confines of individual lives. In a harsh and merciless world, religion alone offers people individual attention, comfort and a sense of purpose in life. It offers a loving father figure who cares and provides for them (Feuerbach). ${ }^{5}$ It offers outcasts a sense of community and promotes the survival of particular groups (Sloan Wilson). ${ }^{6}$

A cardinal reason for the need for God is the nature of human consciousness. A species capable of thought and consciousness inevitably conjures up metaphysical abstractions, substantiated by a deity. Consciousness cannot conceive of eternal non-consciousness, non-existence. It operates metaphorically. The unknown is expressed in terms of the known. The unknown God is spoken of metaphorically in anthropomorphic language. The belief that God reveals himself in the man Jesus implies that what is said about God is expressible in human words and deeds. The nature of consciousness (about which we know little as yet) codetermines thought. This includes its binary structure which offers religion a convenient framework to accommodate the human experience of good and evil.

Of course, religion can also be considered sui generis, a unique phenomenon not reducible to other categories or human activities (see Boyer 2010:91). However, to many believers, it influences their entire way of life and worldview. Faith can be seen as analogous with human imagination. It is pointless to ask whether imagination is true or false: it is imagination. Like dreams, it probably fulfils an indispensable function in the human psyche. Via imagination, I escape from boredom, satisfy vengeful feelings, live out erotic fantasies. Naturally we cannot dwell permanently in an imaginary world, just as we cannot live in a dream our whole life long. Faith that flees from reality prevents us from living to the full. It does, however, enable us to return to reality replenished, for flights of fancy and religious experience inspire us afresh. Dreams, flights of imagination and faith make us see things in a new light, enables us to surmount a problem, write a poem or make a new discovery. All of that is part of the naturalness of religion.

\section{Science is not natural}

From the angle of the human life world, science is not natural or intuitive. Most people experience it as counter-intuitive. At an intuitive level, the earth is flat, the sun rises and the

5.Boyer (2010:22) mentions that Schleiermacher sees religion as a sense and taste for the infinite (Sinn und Geschmack fürsUnendliche)'.

6.Grassie (2010:74-75) identifies the following theories to explain the existence of religion: Religions provide explanations of natural phenomena and existential interests; they meet the need for comfort; they focus on communal rather than individual needs; they offer a mental-moral glue to unite people in social harmony; religion is an illusion. Humans are naturally superstitious and credulous; they are easily swept off their feet by wishful thinking. So religion offers explanations, are easily swept off their feet by wishful thinking. So religion offers explanations, comfort, social order and it may be
superstition, see Du Toit (2011a). stars are not blazing (maybe burnt out) suns. People do not instinctively know the scientific principle underlying the wheel. We perceive the world as a totality and are oblivious of the quantum world of atoms within it. Neither is science concerned about the impact its findings may have on people's naïve ideas (see Wolpert 1993:29). Boyer affirms this: '... religious representations are highly natural to human beings, while science is quite clearly unnatural' (Boyer 2010:85). ${ }^{7}$ By contrast, most people have an intuitive affinity with religion, which centres on their existential experience. The fact that science is 'unnatural' or counter-intuitive does not make it false. Neither does the notion that religion is 'natural' necessarily make it true. The predicates refer to universal human experience.

Besides, the focus of science undeniably differs radically from that of religion. We cannot expect them to look like sister disciplines. Religion amalgamates things; science takes them apart and examines them (see Grassie 2010:166). The unity of the sciences, previously vouchsafed by the Christian tradition, has splintered, and the accent has shifted to the autonomy of individual sciences. ${ }^{8}$ Science is no longer subordinate to religion.

Science ought to view religion as a natural expression of the human spirit. Sociology has reduced it to a cultural phenomenon, ${ }^{9}$ but that does not make it illegitimate. If religion did not fulfil certain basic human needs, it would disappear. To many believers, there are no equivalent, nonreligious means (e.g. science) that satisfy human needs the way religion does.

\section{Religion in a transitional era}

As cultures change, so does religion. The question is whether cultural change, secularisation, globalisation, electronic media and technoscience will lead to the decline and possibly the eventual demise of religion. Does modern scientific knowledge necessarily imply abjuring religion? Statistics on religiosity indicate the reverse. Although religions appear to be growing, ${ }^{10}$ Western Christianity is undergoing a transition, which may be attributed to the influence of science. God is no longer necessary to account for creation. ${ }^{11}$ Science professes to

7..Moreover, a comparison or contrast [between science and religion] only makes sense against some background of similarity, but there is none between scientific theories, held and understood by a very small number of human groups, and the religious imagintion, religious imagination, easily acquired and maintained by millions of people with no effort.' And: 'The results of scientific research may be well-known, but the whole intellectual style that is required to achieve them is really difficult to acquire' a fair idea of what science is up to. People are better informed and, as information a fair idea of what science is up to. People are better informed and, as in
becomes more and more readily accessible, they become even more so.

8.'What can be said with confidence is that by the end of World War I in 1918 Britain had changed so significantly that science and religion had come to be viewed as separate enterprises' (Leaves 2011:64)

9.Thus Durkheim, Freud and Jung explained religions as natural, human creations: "Religions could be explained as "social systems" that are transmitted culturally, through language and symbolism' (in Leaves 2011:65).

10.Leaves (2011:10) cites World Christian Encyclopaedia statistics that the number of people who have no faith at all grew from 3.2 million in 1900 to 697 million in 1970 and 918 million in 2000 . That is roughly one seventh of the world's population.

$111^{\prime} . .$. the revolution in cosmology whose success Galileo ensured was to have enormous social implications, because from now on great institutions like kingship, religion and the moral order could no longer claim the sort of cosmic backing that they always had in previous societies' (Leaves 2011:59). 
explain all reality. There are other factors as well. Globalism brings different cultures together, making shared spirituality possible. There is less concern about a hereafter. ${ }^{12}$ The accent is on the present and an experientially rich life on earth. Life expectancy is increasing steadily. ${ }^{13}$

Although many leaders of mainstream churches are in touch with scientific developments and accept the sentiments consonant with modern ideas, it is extremely difficult to change the church 'from within'. ${ }^{14}$ Mainstream churches should ask themselves how much traditional dogma can be forfeited without forfeiting their distinctive identity. Should their age-old creeds be modified to accommodate presentday thinking? To many, it would imply loss of ecclesiastic identity.

The tacit assumption is often that the faith need not be sacrificed because not all of it is literally true. Many believers continue to belong to mainline churches though they no longer accept traditional doctrines that conflict with a modern worldview.

\section{Progressive believers and spirituality: Closer to a scientific worldview?}

The reason for focusing on new spirituality is that some of these movements exemplify the endeavour to articulate religion in ways that do not conflict with a scientific worldview. ${ }^{15}$ Such attempts are few and far between in South African mainline churches where many members remain antagonistic to evolutionary cosmological ideas.

To what extent is the growth of diverse spiritual groups that are mushrooming alongside the mainline churches prompted by anti-fundamentalism and a scientific worldview? Many contemporary, religiously oriented people find the generic term 'spirituality' unsatisfactory because the groups are too diverse, and they prefer to speak of spiritual pluralism. Spiritual groups do not aspire to 'church-hood', do not produce creeds and dogmas, are not necessarily missionary in their approach, are not structured organisationally and so forth. It is not always clear to what extent the groups differ from their original denominations and what they put in the place of the doctrines they have abandoned. There may well be many parallels with traditional Christian spirituality.

Many spiritual groups may be considered progressive and are often anti-theistic, ${ }^{16}$ postmodern, secular and rational.

12.This life is all that we have and we must take responsibility for ourselves, our fellow humans and our planet. Belief in God becomes redundant: a figment of our imaginations that can be discarded' (Leaves 2011:30)

13.'We must face our own death without the comfort of an afterlife; we must endow our projects with significance from within; we must find it in ourselves to figh for justice though the odds may be against us; and we must self-consciously build a new sense of community based on recognition of our and others' autonomic choices' (Joseph Levine, in Leaves 2011:31; see also Du Toit 2009)

14.Grassie (2010:189) rightly comments: 'To try to read science back into ancient scriptures is an absurd way to validate a tradition.' There may be passages where it happens to be feasible, but in many more instances, it will be impossible. The Bible did not set out to address the scientific worldview of people who were to live two millennia later.

15.In South Africa, the New Reformation Network (NRN) and the Centre for presentday Spirituality (CPS) are two examples.

16.A new breed of theist is emerging in nearly every denomination and religion around the globe. If we had a creed, it might simply be this: Reality is our God, evidence is our scripture, and integrity is our religion (see Dowd n.d.)
Other attributes are a non-literal reading of the Bible; naturalism; ecological awareness; accent on meditation, mysticism and silence; the influence of Eastern religions; preference for alternative conceptions of supernatural powers (e.g. synchronicity). Analogous with the thinking of the 19th century philosopher, Emerson, the emphasis is on the potential of our unutilised inner abilities, creativity and spiritual depth (see Du Toit 2011b).

Many religious progressives would like to remain more or less true to their Christian tradition but hone their faith to conform to present-day scientific ideas. They insist on anti-fundamentalist scriptural exegesis and read biblical miracles and supernatural stories against the background of our contemporary worldview. It is very much an approach 'from below' with the accent on immanent transcendence. ${ }^{17}$ Whether these changes will have an impact on scientists who are critical of religion is a moot point.

\section{Different levels of complexity in religion and science}

To many scientists, the disparity between a scientific and a religious worldview is more problematic than to believers. Some believers appear to have no difficulty in reconciling the two opposing worlds in their lives, but from a scientific point of view, science and religion are irreconcilable (Leaves 2011:38). In order to compare them, one has to put them on a par and that is not feasible. Religion is far more complex than science. When science does confront us with really complex profundity it is no less mysterious than religion. Religion is more complex than science because it has to answer complex existential questions, allay human fears and meet personal needs, whereas science simply focuses on the building blocks of reality. The nature of a building block is fairly easy to identify, define and formulate theoretically with no regard to personal complexities. Science focuses on concrete reality whilst religion hones in on the intricacies of mind where issues of meaning, relationships, guilt, the future and the like arise - questions usually experienced as highly complex.

As we know, higher levels of complexity cannot be assessed according to criteria that apply at lower levels. Laws describing emergent phenomena are independent of laws at lower levels. Thus the laws of thermodynamics are independent of the laws governing the motion of atoms in classical quantum mechanics. At higher levels, we are dealing with new factors. Uncertainty at quantum level, for instance, displays order at higher levels. Erwin Schrödinger (1992) describes it thus:

Only in the co-operation of an enormously large number of atoms do statistical laws begin to operate and control the behaviour of these assemblées with an accuracy increasing as the number of atoms involved increases (with reference to the completely disorderly heat motion of atoms). (p. 10)

The principle is that circumstances at higher or more complex levels differ from those at primary levels where we deal

17.Immanent transcendence relates to Whitehead's process philosophy: 'Whitehead's God is radically transcendent and radically incarnate at the same time' (Grassie 2010:195; see also Du Toit 2011b). 
with basic, physical components. Other factors, that have no influence at lower levels, come into play. The same applies to organisms. The laws governing the motion of bacteria are far simpler than those governing a leopard on the prowl. The basic laws of nature do not change, but a combination of complex factors come into play at higher levels.

\section{McKenzie (2011) describes what this means for theology:}

So, by analogy, we might consider the notion that theological truth is 'robust' and independent of the laws or concepts which govern behaviour at lower strata levels, such as anthropology, psychology and biology. (p. 231)

Though one may not agree with this specific example, the principle could well be valid. To cite another example: science deals with facts, not emotions. ${ }^{18}$ Religion is at the epicentre of human emotion. We are only beginning to understand the complexity, existential impact and biological drives underlying this.

\section{The role of metaphysics in religion and science}

Directly or indirectly, science and religion both display metaphysical features. Metaphysics deals with metaempirical questions: existence and the ground of existence. The question of what underlies sensorial accessible reality is peculiar to philosophy, religion and science. It entails issues like the source, cause and agency of everything that exists - questions of causality. Comte sees metaphysics as the second phase of human evolution, myth being the first and science and pragmatism the last phase. However, his is a modernist definition which assumes that pragmatism has no metaphysical undertones. Idealism and realism cannot be fully separated - neither in religion, nor in philosophy, nor in science. Science is not a-metaphysical, and religion cannot circumvent the nature of physical reality. In similar vein, scientific language, like religious language, depends on models, images and metaphors.

We now turn to the role of metaphysics in human thought and how it changes in the current popular climate of emergence. We start with the ancient Greeks.

The pre-Socratic cosmologists are a beacon in philosophy. They did not look for the nature and causes of reality in myths, anthropomorphic gods and superstition but sought the origin and genesis of everything in the natural world. The fascinating thing is the aptness of many of their descriptions although it may well have been coincidental. If those early cosmologists' ideas had been included in the Christian Bible, scientists would have been much more interested in it. To take a few examples: Anaximander (611-547 BCE) saw the origin of the cosmos in formless primeval matter from which everything evolved. In the beginning, the world was

18.That could be said of all sciences. But is it true? Pierre Hadot (quoted in Wynn 2005:134-135) says, with reference to the early Greek, philosophers, that their primary concern was not with ideas but with life questions, existential attitudes "which "attitud" which acterised the "attitudes" which are typical of Stoicism as "tension", "duty", and "vigilance", and those typical of Epicureanism as "serenity" and the "joy of existing"' (Wynn 2005:135). fluid and its heat and humidity generated low-order living beings, which gradually evolved into organisms by adapting to their environment. Originally humans were aquatic fish (cf. evolution). Anaximenes (588-524 BCE) saw the source as air, which gave rise to everything through rarefaction and condensation. There are an infinite number of worlds. The Pythagoreans accentuated proportion, order and harmony in the universe as a result of numbers. Numbers are the secret and foundation of the cosmos (a hallmark of science is measurement based on numbers). According to them, the earth revolved around a central fire (not yet the sun, but close enough!).

A feature of early cosmological thought that is particularly pertinent to our argument is that their empirical (sensory) focus inescapably included non-empirical, metaphysical concepts (I argue that present-day science cannot do without these either). Parmenides (from the Eleatic school) is the cardinal example. Absolute reality is Being: Non-being is unreal, is becoming that can be identified with fluidity and flux. Being is self-generated and cannot change into anything other than itself. Parmenides distinguishes between sense and reason. The senses offer us the phenomenal world which is the world of appearances. Only reason can apprehend true Being. That is a basic principle of idealism: Truth is knowable in the domain of reason, not in the sensory sphere. (In passing it should be noted that Parmenides, the father of idealism, was a materialist as well: Being, supreme reality, occupies space and is finite. What occupies space is matter.) This is relevant because it is futile to contrast idealism and materialism. Just as humans are not only bodies or only minds, so science without (metaphysical) ideas or religion without physical reality is not possible. That is the basis of the mutual accommodation of science and religion. Below we amplify this statement with reference to Aristotle.

Metaphysics deals with essences. They could also be called ontological. Plato is the father of essentialist philosophy. The essence of things lies in the ideal world rather than the flux of our world. Essences (eidoi) are fixed and immutable, hence true. Aristotle rebelled against this notion. He is the father of metaphysics (Berger 1993:34).

Parmenides posed the essentialist, ontological question: What is it that is? Why is there something and not nothing? Plato broadened this essentialist question (what is) to include judgement, for example, 'it is beautiful', 'it is good'. Aristotle went even further, maintaining that, according to Plato, there are two kinds of judgement: judgements that pronounce on the qualities and relations of things and ontological judgements. The latter always have a further dimension. 'The wood is white' is not so much a matter of the colour of the wood - it could have been brown (the colour of the wood is a chance, an accidental attribute, distinct from its substantive nature). The colour does not concern the essence of wood per se. Aristotle found this unacceptable and, good scientist that he was, he brought ideas down to earth and to the object under investigation. The essence of things is necessarily immanent, not something that exists in a separate world of 
ideas. That makes Aristotle the father of physics as well, but Plato's problem of mutability still had to be solved.

Aristotle distinguished between things that change (i.e. move) and things that are immutable (i.e. unmoving). The latter are things like mathematics that do not change from one day to the next. But how durable are things that move, like the sun? (In the Aristotelian paradigm, the sun still moved from east to west every day.) Movement may cease when its cause disappears, which could stop even the movement of the sun. Hence he posited an unmoved mover who is not subject to change (Berger 1993:36). Whereas moved movers are natural causes and are material, the unmoved mover is not material. The unmoved mover belongs to a different order that exists alongside the physical order. Via the unmoved mover, Aristotle arrived at being as the object of metaphysical thought. He called this order the first philosophy, which deals with immaterial forms: the soul and, of course, the divine. It is not the order of metaphysics but a condition for it.

That enabled Aristotle to distinguish between material and immaterial substances. Physics is not universal because it focuses on concrete objects. Metaphysics is a universal science because it deals with both immaterial and material substances. If you know the immaterial substance (that which causes things), you can know both the physical characteristics and being itself (inasmuch as it exists - see the distinction between substantial and accidental characteristics). Immaterial substance, then, is the answer to Parmenides's ontological question (why is there something?), as well as the question about physical or sensorial observable objects (see Berger 1993:38-39). It could mean looking at an organism without inquiring what makes possible life, the planet, solar systems or the cosmos.

Why is this pertinent today? Simply because Aristotle's immanent, physically centred approach did not get rid of metaphysics. Unlike Plato, Aristotle was not a dualist, yet he still distinguished between physical being and Being as such. The sciences, too, cannot get away from the metaphysical aspect of reality or being.

\section{Examples of the metaphysical dimensions of natural science}

Evolution depends on chance and necessity. How it will proceed in time is unpredictable. ${ }^{19}$ Chance is such a huge potential force that it virtually assumes divine features. Chance (random possibility) and infinitely large numbers are interdependent. Multiplicity (number, relation, infinity) is the secret of the universe and of all life on our planet. Without multiplicity and the possibilities it permits in certain relationships, there would have been no creation or even life. (Note, this does not endorse the so-called anthropic principle, which maintains that the universe 'awaited', as it were, the advent of humans.) We know that the evolution of the universe relies on huge numbers, as well as on the Goldilocks principle of balance: neither too many nor too few.

Without fear of contradiction one could aver that nowadays science has superseded philosophy as the main arbiter of that which exists, the nature of reality, ontology, being. Although its answers are based on physical insight, they contain a healthy admixture of metaphysics. Examples of metaphysical questions in science include the following: why natural laws are what they are; the metaphysics of chance; ${ }^{20}$ the metaphysics of multiplicity, space and time; the quantum world and parallel universes; the origin of matter (energy); the situation before the Big-Bang; the nature of autopoietic systems; the nature of human consciousness and the role of quantum physics in it; the miracle of emergence and the nature of creativity. Below we explore one such question.

\section{Successful new emergent developments depend on successful chance, which in its turn depends on large numbers}

The following is proof of the potential for biological diversity. There are twenty amino acids which, linked in certain combinations in long polypeptide strings, constitute the basic components of proteins, which in their turn determine the incidence and functioning of organisms. Regis (2008) cites this example:

If a hypothetical protein was 200 amino acids long (which is not exceptionally long for a protein), then given the fact that there were 20 different amino acids that could occupy each of those 200 spaces, there were $20^{200}$ possible amino acid combinations, which was a number approximately equal to $10^{260}$. By any standard, that was a big number; the number of elementary particles in the universe, by contrast, was thought to be 'only' $10^{80}$. (pp. 95-96; also see Kauffman 2008:122)

That indicates the vast potential of chance to produce diverse forms of life. If life on our planet had to start from scratch (i.e. without building on antecedent life forms), it would probably have been very different. Chance introduces a completely different ball game from a process based on causality.

A typical cell comprises some 20000 different proteins. A small cell might contain 100 million protein molecules. The human body has some ten trillion $\left(10^{13}\right)$ cells and 210 types of tissue. In addition, some 100 trillion prokaryotic cells (Ecoli bacteria) live in our intestinal tract (see Grassie 2010:167-168).

When we look at the universe of the human brain, we are again overwhelmed by vast numbers. We have about 100 billion neurons, each with on average 7000 synaptic connections. A three-year-old child has about $10^{16}$ synapses. It means that the number of neurons in the human brain roughly equals the number of stars in the milky way - plus-minus 100 billion (Grassie 2010:94-95). But that is only half the story. Add to

20.'Metaphysics of chance' in this context do not include statistics and ways of calculating probability (randomness, uncertainty) although we may still expect new insights and models to develop in future as stronger computers become available. This refers to chance with a capital C, as metaphysical entity, where chance is personified agency (see Bartholomew 2008:16, 17). Many statistical mistakes wer made in the past. The Intelligent Design Movement can be singled out (Dembski) as can highly respected authors like Gould, Davies and proponents of the anthropic principle (see Bartholomew 2008:81-82, 97ff., 109-115). 
this the brain's interactions with the outside world, and an infinite number of creative possibilities opens up. Consider, moreover, that human consciousness and thought rely on each synaptic contact as well as a combination of numerous simultaneous contacts. It follows that a human person is necessarily creative, imaginative and highly complex. That is apparent in the artworks, literary creations and religious activities that are hallmarks of human life. Restricting the human brain religiously, philosophically or in any way whatever is to restrict a whole universe of emergence.

This example of large numbers underlying emergence raises the question whether emergence will not inevitably revert to metaphysics. In the case of linear causality that posits just one entity as the origin of everything, that entity was almost unavoidably credited with all manner of speculative attributes. (Examples are Parmenides's Being, which is selfidentical, indivisible, unmoving and not tied to any locality; Plotinus's One; and the Christian God.) Emergence, which entails large numbers and a vast multiplicity of factors, makes it far more difficult to develop metaphysical constructs. That does not rule out the prospect of new metaphysical designs. Kauffman already links creativity (emergence) with the sacred - the raw material of a new God concept. In time to come, more powerful computers, new methods and insight will probably make it possible to map, even predict, multiplicity and even chance and probability. Nonetheless it is equally likely that new metaphysical questions will keep surfacing.

The human brain is incontestably the best example of emergence in the universe. Human consciousness, whilst immaterial, is a product of matter, of electrochemical processes. Not that our imagination is not spellbound by the manifestations of emergence in the knowable universe: the physicality that preceded the big bang, the birth of stars, the generation of planets by exploding suns and the origin, diversification and evolution of life. Just as every person is unique, so the emergence of each new species is unrepeatably unique. That is why it is foolish to try to reduce the multifaceted origin of any bit of reality to some underlying component.

Whereas science can identify the laws that account for the evolution of life, it cannot predict the type of life that will be based on those natural laws. That is why emergence opposes any form of reductionism. Self-organisation (cf. cellular autopoietic systems) is a case in point: 'Self-organization ... is both emergent and not reducible to physics' (Kauffman 2008:101). Emergence should be seen as a metaphor for all the complex processes that give rise to new developments, like large numbers, adequate time, ideal circumstances and chance. That makes the concept of emergence a totally different causal model from the traditional metaphysical version of causality.

\section{Emergence supersedes the dominance of causality (essentialism)}

The metaphysical question is basically the question of causality. The traditional view was reductive: One cause (God, the unmoved mover, natural law) was posited as the source of all evolution. That is not how we see it today. Causality is not linear; not ascribable to a single cause; not necessarily deterministic; not necessarily predictable; often dependent on multiplicity rather than a single cause and so on. A linear type of causality is essentialist in that the outcome of vastly complex processes is attributed to a single agency. Such a model might apply to closed systems, but if reality is envisioned on a grander scale, it is simply too open and receptive to unforeseen input to be predicted with any accuracy.

After Aristotle, causality became the abracadabra determining all new phenomena. Now it has been joined by chance, which introduced contributory factors like environmental influences that differ from one place and time to the next. As a result, it is impossible to predict causal outcomes with any certainty, which applies par excellence to a complex species like Homo sapiens. The concept of emergence stands causality on its head.

Heidegger (1975) pointed out that the Latin word res means something that affects you (that which concerns somebody, an affair, a contested matter, a case at law). It differs from the Latin causa:

In its authentic and original sense, this word in no way signifies 'cause'; causa means the case and hence also that which is the case, in the sense that something comes to pass and becomes due. (p. 175)

That is how we should understand causality, not in the sense of a cause or an effect. That makes 'emergence' a more apposite term because it accentuates the present circumstances that give rise to a phenomenon. In contrast to the Greek notion of One Immaterial Unmoved Mover, we now posit a multitude of material, moving entities as the ground of all that exists!

To return to Aristotle, he distinguished between physically observable beings and Being (which entails the ground of being and other metaphysical questions). In the case of observable objects, Kant distinguishes a Ding an sich because we can never know the 'true' essence of things. Hence he concurred with Plato's notion of a different order, the difference being that to Kant that order is not knowable. He distinguishes between a sensory world (sensibile) and a mental world (intelligibile) (Du Toit 1984:149). Humans also have a super-sensory nature, which manifests itself in moral laws. It differs from the natural world because it presupposes an ideal world (Berger 1993:27). But the super-sensory world is not supernatural, even if it transcends the natural world.

Our position that science cannot do without its quota of metaphysical baggage will probably be repudiated by many scientists because science works 'on the ground' on methodologically established inferences. These are not, however, without problems. All knowledge is uncertain, in varying degrees (see Bartholomew 2008:232ff.). However, the bigger questions raised by this 'work on the ground' are 
unmistakably metaphysical (questions about the nature and origin of existing realities). Can science answer the question about being and Being - the ground of the being of objective physical reality? That is the question why the universe and its laws are the way they $\operatorname{are}^{21}$ and not different (the Ding an sich in present-day science). The only answer is that it simply is what it is. It is the character of Being that reveals itself to us in its enigmatic uniqueness. The way science answers (does not answer!) the question about Being may be experienced by some as profoundly unsatisfactory. Scientists may respond that these questions are simply unanswerable. For example: Natural laws are what they are, we do not know why. ${ }^{22}$ Life owes its character to chance: ask no more. We can never know the nature and circumstances of singularity (the moment that triggers the Big Bang). There is no adequate reason for the evolution of the human brain (thought and consciousness), for it is in fact an 'over achievement' in that it equips us with far greater capacity than is needed for survival. Science will no doubt gain greater clarity about the nature of the physical world, but the answers it offers are not directed to human existence. For existential answers, we have to turn to other sources. Hence science does not yield 'original' truth; it simply explains an existing domain of truth. It does not get beyond an empirical explanation of empirical data. If it were to move closer to the question of truth - to the essential revelation of that which exists - it would be philosophy (Du Toit 1984:49).

\section{Conclusion}

Religion, like science, is a natural part of the human condition, but they are two different facets and do not function at the same level. That does not mean that they do not influence each other, and they should certainly relate to each other. Both science and religion are constantly changing, albeit for different reasons. Christian theology and faith are in a transitional phase. How it will evolve depends partly on its interaction with the sciences. Metaphysical features in science do not make it unscientific. They are simply unavoidable. Religion does not have to be supernatural to be meaningful. It could be reinterpreted in ways that do not conflict with basic scientific ideas. The challenge is to do so plausibly.

God is a metaphor for life that is emerging in all its variation and possibilities. These possibilities with their inherent openness are evident in diverse ways in recent thinking. It is analogous with Heidegger's enlightenment of being, Levinas's Other ${ }^{23}$ and Sartre's notion of pour

21.Kaufmann (2008:131) writes: '... we scientists have believed that the universe and all in it are governed by natural laws, Newton's, Einstein's, Schrödinger's. Let me call this the Galilean spell. Under this spell, we have believed reductionism for over 350 years.'

22.To Grassie (2010:192), the feasibility of science is proof of the idea of God by another name: 'Science itself is an "intimation of transcendence".'

$23 . \ldots$ it is precisely because the face of God is transcendent that the only form in which you will ever find the face of God is in the face of the neighbor, which is where you should direct all your attention' (Robbins 2006:79). soi. It is the newness of the world (Heidegger's Welt) transformed from matter (Heidegger's Welt-Erde distinction) (Du Toit 1984:46-48). It is the newness of the improvisation that emerges uniquely in a familiar work of art (Gadamer 1977:41ff.). It is Caputo's concept of an event. ${ }^{24}$ It is the 'netineti' ('not so, not so!', in response to any final interpretation of reality) of the Chinese Kung Fu (Du Toit 1984). None of these possibilities is dependent on the supernatural. It is part of the natural order that, in its openness and novelty, can be termed transcendent. From our perspective, it is immanent transcendence in all its startling newness.

\section{Kauffman (2008) epitomises this position:}

Then the unfolding of nature is God, a fully natural God. And such a natural God is not far from an old idea of God in nature, an immanent God, found in the unfolding of nature.... This that we discuss is a science, a world view, and a God with which we can live our lives forward into mystery. (p. 288)

To sum up: Recent fascinating scientific developments enable us to broaden the constricting notion of causality with the concept of emergence. That implies millions of years of evolutionary development into startling new life forms. Science can never explain everything. Ultimate questions exemplified by Parmenides' 'why anything at all?', Aristotle's Unmoved Mover, Kant's Ding an sich - are unanswerable, even by science. Inasmuch as religion keeps raising these tantalising questions and seeks to integrate them with human life, it will remain a human datum.

\section{Acknowledgements Competing interests}

The author declares that he has no financial or personal relationship(s) which may have inappropriately influenced him in writing this article.

\section{References}

Badiou, A., 2006, Briefings on existence, State University of New York Press, New York http://dx.doi.org/10.1017/CBO9780511807701

Bartholomew, D.J., 2008, God, chance, purpose, Cambridge University Press, Cambridge. http://dx.doi.org/10.1017/CBO9780511807701

Berger, H., 1993, Wat is metafisica? Een studie over transcendentie, Van Gorgum, Assen, Maastricht.

Boyer, P., 2010, The fracture of an illusion: Science and the dissolution of religion, Vandenhoeck \& Ruprecht, Göttingen.

Dowd, M., n.d., 'The advent of evolutionary Christianity: conversations at the leading edge of faith', in Skeptic Money, viewed n.d., from http://www.skepticmoney. com/the-advent-of-evolutionary-christianity-conversations-at-the-leading-edgeof-faith/

Du Toit, C.W., 1984, 'Die metaforiese spreke oor God', ongepubliseerde PhD-proefskrif, Navorsingsinstituut vir Teologie en Religie, Universiteit van Pretoria.

Du Toit, C.W., 2009, 'An immanent approach to death: Theological implications of a secular view', HTS Teologiese Studies/Theological Studies 65(3), Art. \#296, 8 pages. http://dx.doi.org/10.4102/hts.v65i1.296

Du Toit, C.W., 2011a, Horseshoes, angels and other UFOs: Rethinking faith in light of present-day superstitions', Verbum et Ecclesia 32(1), Art. \#488, 9 pages. http:// dx.doi.org/10.4102/ve.v32i1.488

24 'The crucial move lies in treating the event as something that is going on in words and things, as a potency that stirs within them and makes them restless with the event' (Robbins 2006:50). That is what Vattimo calls secularisation: '... which means not the abandonment or dissolution of God but the "transcription" of God into time and history (the saeculum), thus a successor form of death of God theology.' He sees nihilism and kenosis as parallels. 'Nihilism is the emptying of Being into interpretive structure; kenosis is the becoming nothing of God as transcendent deity' (Robbins 2006:74). 
Du Toit, C.W., 2011b, 'Shifting frontiers of transcendence in theology, philosophy and science', HTS Teologiese Studies/Theological Studies 67(1), Art. \#879, 10 pages. science,
$\mathrm{htt}: / / \mathrm{dx}$.doi.org/10.4102/hts.v67i1.879

Gadamer, H.G., 1977, Aktualität des Schönen, Philip Reclam, Stuttgart. PMid:21129964

Grassie, W., 2010, The new sciences of religion: Exploring spirituality from the outside in and bottom up, Macmillan, New York. http://dx.doi.org/10.1057/9780230114746, PMid:21129964

Heidegger, M., 1975, Poetry, language, thought, Harper \& Row, New York.

Kauffman, S.A., 2008, Reinventing the sacred: A new view of science, reason and religion, Basic, New York.

Leaves, N., 2011, Religion under attack, Polebridge Press, Salem.
McKenzie, R.H., 2011, 'Emergence, reduction and the stratification of reality in science and theology', Scottish Journal of Theology 64(2), 211-235. http://dx.doi. org/10.1017/S0036930611000068

Regis, E., 2008, What is life? Investigating the nature of life in the age of synthetic biology, Oxford University Press, Oxford.

Robbins, J.W. (ed.), 2006, After the death of God: John D. Caputo and Gianni Vattimo, Columbia University Press, New York.

Schrödinger, E., 1992, What is life?, Cambridge University Press, New York.

Wolpert, L., 1993, The unnatural nature of science, Faber \& Faber, London, Boston. PMCid:47099

Wynn, M.R., 2005, Emotional experience and religious understanding: Integrating perception, conception and feeling, Cambridge University Press. Cambridge. http://dx doi.org/10.1017/СВ09780511610509 